\title{
FULL FAITH AND CREDIT OF ADJUDICATION OF JURISDICTIONAL FACTS
}

\author{
PaUt E. Farrier*
}

HE construction and application of the so called Full Faith and
Credit Clause of the United States Constitution ${ }^{2}$ and its attend-
ing acts of Congress ${ }^{2}$ have resulted in not a little confusion in the principles involved and the problem has been handled, seemingly, with a lack of understanding by judicial opinion. The attempt here is to clarify, in a measure at least, the thought upon the subject with respect to impeachment of judgments of sister states on the grounds of lack of jurisdiction over the person of the defendant ${ }^{3}$ and particularly with reference to contradiction of an adjudication or recital of the existence of that jurisdiction.

At first the cases were somewhat in confusion ${ }^{4}$ regarding the effect of a foreign judgment ${ }^{5}$ but it is now recognized that the domestic forum, in a

* Of the Illinois Bar.

\& U.S. Const. Art. 4, § I:

"Full Faith and Credit shall be given in each state to the public Acts, Records, and judicial Proceedings of every other state. And the Congress may by general laws prescribe the Manner in which such Acts, Records, and Proceedings shall be proved, and the effect thereof."

This principle was not new in our history. For history of this Constitutional provision see paper by George P. Costigan Jr. in 4 Col. L. Rev. 470 (rgo4).

2 I Stat. I22 (I790), 28 U.S.C.A. \$687 (I928):

"The said records and judicial proceedings, so authenticated shall have such faith and credit to them in every court within the United States as they have by law or usage in the courts of the state from which they are taken."

See also 2 Stat. 298 ( 1804 ), 28 U.S.C.A. $\$ 688$ ( $x_{928}$ ).

3 There may be certain other valid reasons for not according full faith and credit to a judgment of a sister state with which this article is not concerned, such as when the judgment is for the enforcement of a penalty. See Wisconsin v. Pelican Ins. Co., x27 U.S. 265 (1883); Heston v. Chicago Nat. City Bank, 280 Fed. 525 (C.A.D.C. 1922).

4 See Armstrong v. Carson's Exr., 2 Dall. (U.S.) 302 ( $x 794$ ), holding that the only issue was the fact of the judgment and that was to be determined by inspection of the transcript; Green v. Sarmiento, to Fed. Cas. No. 5,760 (C.C.Pa. I8ro); Bigger v. Hutchings, 2 Stew. (Ala.) 445 (1830); Noble v. Gold, I Mass. 4 ro (I805); Bartlet v. Knight, x Mass. 401 (I805); Bissell v. Briggs, 9 Mass. 462 (I8r3); Gleason v. Dodd, 4 Metc. (Mass.) 333 (r842); Hitchcock v. Aicken, I Cai. (N.Y.) 460 (I803); Hubbell v. Coudrey, 5 Johns. (N.Y.) I32 (I80g); Taylor v. Bryden, 8 Johns. (N.Y.) I73 (I8II); Pawling v. Willson, I3 Johns. (N.Y.) I92 (I8I6); Hazard v. Nottingham, Tapp. (Ohio) 146 (I8I7); Betts v. Death, Add. (Pa.) 265 (I795); Flourenoy v. Durke, 4 S.C.I. 256 (I808); Glasgow v. Lowther's Admx., Cooke (Tenn.) 464 (I8I3); Winchester v. Evans, Cooke (Tenn.) 420 (1813); Lawrence v. Roberts, 2 Overt. (Tenn.) 236 (I8I4).

5 The use of the term "foreign judgment" throughout this discussion is used for the sake of convenience and unless otherwise specified the term refers to the judgment of a state of the 
suit on a judgment rendered by a sister state, may inquire into the jurisdiction of the sister state to render the judgment in question. If it is found that the latter did not have jurisdiction to render the judgment, the domestic forum is not compelled to recognize the judgment under the Full Faith and Credit Clause. ${ }^{6}$ This is of course based upon the principle that a judgment rendered without jurisdiction is invalid and constitutes no judgment at all. ${ }^{7}$ As a matter of fact, it should be noted, the domestic forum is required by the Due Process Clause of the Constitution ${ }^{8}$ not to recognize a judgment rendered without such jurisdiction, ${ }^{9}$ since the enforcement of such a judgment amounts to the taking of property without due process of law. Thus the inquiry would seem to be merely what constituted jurisdiction. Certainly, it is at least necessary to have clearly in mind the concepts of jurisdiction before any further discussion, though no attempt will be made here to cover the subject exhaustively.

Jurisdiction has from its beginning been based upon the physical power of the court, ${ }^{\text {xo }}$ and our concepts of the present are still based mainly upon this principle. Besides personal service, which began with physical custo-

United States other than of the forum and does not include judgments of foreign countries. It should be noted, however, that the principles underlying the recognition of the latter type of judgments are the same as those involved in the former with the exception that recognition of judgments of foreign countries is not mandatory as is the recognition of the judgments of sister states. Thus if the court rendering the judgment lacked jurisdiction to do so, that judgment should not be recognized by the courts of this country regardless of whether the judgment is one of a sister state or one of a foreign country. See: Bischoff v. Wethered, 9 Wall. (U.S.) 8I2 (1869); French Mut. Gen. Soc. v. U.S. Fidelity etc. Co., 203 Fed. 558 (D.C. Md. I9I3) (reversed in $2 \mathrm{I}_{2}$ Fed. 620 (C.C.A. $4_{\text {th }} \mathrm{Ig}_{\mathrm{g}}$ )). But where the judgment is one of a foreign country it is not necessarily true that it will be recognized even though the court had jurisdiction to render the judgment. See: Hilton v. Guyot, r59 U.S. II3 (I895).

${ }^{6}$ The holdings on this point are too numerous to set forth in detail. See 32 L.R.A. (N.S.) 905,909 (IgII).

7 The courts of the United States follow the principles set forth in Lord Blackburn's opinion in Godard v. Gray, L.R. 6 Q.B. 139, I48 (1870)

".... it seems to follow that anything which negatives the existence of that obligation (created by the foreign judgment) or excuses the defendant from performance of it must form a good defense to the action."

${ }^{8}$ U.S. Const. Amendm. V. and Amendm. XIV $\S$ I.

9 Pennoyer v. Neff, 95 U.S. $7 \mathrm{I}_{4}$ (1877); Connecticut Mutual Life Ins. Co. v. Sprately, I72 U.S. 602 (I899); Old Wayne Life Assn. v. McDonough, 204 U.S. 8 (I907); Wetmore v. Karrick, 205 U.S. I4I (1907); Riverside etc. Cotton Mills v. Menefee, 237 U.S. I89 (1915), Bryant v. Shulte's Exr., I47 Ky. 268, I44 S.W. 28 (I9I2); Central Pa. Conference Ed. Soc. v. La Rue, I62 Mo. App. 93, I48 S.W. I52 (IgI2).

so "The foundation of jurisdiction is physical power" Holmes. See McDonald v. Mabee, 243 U.S. 90 (rgr 7 ). 
$\mathrm{dy},^{\mathrm{Ir}}$ as a basis for jurisdiction to render a personal judgment $\mathrm{t}^{\mathrm{t2}}$ it is conceded that jurisdiction exists if the defendant consents to be sued. ${ }^{13}$ There was no need to send the sheriff after some one if he came voluntarily or consented to be bound by what took place in his absence. It is further admitted generally ${ }^{14}$ that the domicil of the defendant within the jurisdiction is a good basis for jurisdiction. ${ }^{x 5}$ Presumably the sheriff could always reach one who was domiciled within the jurisdiction and if absent or in hiding there was all the more reason as a matter of convenience and necessity to allow a personal judgment based upon such jurisdiction. It has also been contended that jurisdiction might be based upon citizenship since a sovereign naturally has control over its subjects. ${ }^{16}$ Until recently ${ }^{17}$ this has been the extent of the various grounds of jurisdiction, though now the doing of certain acts within the state is recognized as giving the court jurisdiction to render a personal judgment, at least if connected with such acts. $^{18}$

II I Holdsworth, History of English Law (I93I), 2Io; Collins v. Page, Styles Reports I24 (I649). For a parallel in Roman law see the first two paragraphs of the first of the Roman Tables (45० B.C.). The writs of attachment and distringas, capias, outlawry and the statute of 9 and ro William $I I$ were all designed to secure custody of the defendant. Finally the statute of $x_{2}$ George $I$, c. 29 was passed in I725 out of which the modern method of taking judgment upon default arose.

I2 This discussion is limited to the question of giving full faith and credit to personal judgments. It is suggested, however, that the principles stated herein are applicable to other judgments upon the application of other jurisdictional factors.

${ }^{23}$ The most common case of jurisdiction by consent is when the defendant makes a general appearance in an action against him in which he has not been served with process. See: Hill v. Mendenhall, 2 I Wall. (U.S.) 453 (1874); Interior Constr. etc. Co. v. Gibney, x60 U.S. 2 I7 (r895); Western Loan etc. Co. v. Butte etc. Minn. Co., 2ro U.S. 368 (rgo8). As to non-residents see Shields v. Thomas, I8 How. (U.S.) 253 ( 1855 ).

I4 The contrary has been held in some cases. See: De La Montanya v. De La Montanya, II2 Cal. Ior, 44 Pac. 345 (1896), and Raher v. Raher, I50 Ia. 5Ir, I29 N.W. 494 (I9rr).

Is See: Schlawig v. De Peyster, 83 Ia. 323,49 N.W. 843 (r89r); Henderson v. Staniford, I05 Mass. 504 ( 1870 ); Pinney v. Providence Loan \& Inv. Co., I06 Wis. 396,82 N.W. 308 (I900); Wharton, Conflict of Laws ( 3 d ed.), § 649 .

${ }^{16}$ Smith v. Grady, 68 Wis. $2 \times 5,3$ I N.W. 477 ( 1887 ). However, since it is doubtful whether one is a citizen of a State of the United States, see Hammerstein v. Lyne, 200 Fed. I65 (D.C. Mo. IgI2), the significance of this basis of jurisdiction in the present discussion is unimportant; Ouseley v. Lehigh Valley Trust \& Safe Deposit Co., 84 Fed. 602 (C. C. Pa. I897); Grubel v. Nassauer, 2IO N.Y. I49, IO3 N.E. III3 (rgI3), noted in 27 Harv. L. Rev. 464 (IgI4).

${ }^{27}$ It was not until the middle of the rgth century that it became generally recognized that a personal judgment could be recovered against a foreign corporation. See The Lafayette Insurance Co. v. French, I8 How. (U.S.) 404 (I855); Peckham v. North Parish in Haverhill, I6 Pick. (Mass.) 274 (1834); McQueen v. Middletown Manufacturing Co., I6 Johns. (N.Y.) 5 (I8Ig).

${ }^{18}$ See: Fenderson, The Position of Foreign Corporations in American Constitutional Law (Igr8), c. 5; Cahill, Jurisdiction over Forejgn Corporations, 30 Harv. L. Rev. 676 (I9I7); 
It should be pointed out that there are two types of jurisdictional facts. One speaks of domicil, personal service, doing business etc. as being jurisdictional facts but behind each of these jurisdictional facts there are other facts the existence of which make as a matter of law for the existence of what is called the jurisdictional fact. Thus in domicil there are certain facts which must be true before it can be said that the defendant was domiciled within a given state. In personal service certain other facts are necessary and so on.

In each case it is necessary for the court to determine four things. First, that facts $\mathrm{A}, \mathrm{B}$, and $\mathrm{C}$ are present; second, that such facts, as a matter of law, constitute the jurisdictional basis under consideration; third, that because of such jurisdictional basis the court may assume jurisdiction over the defendant; and fourth, that jurisdiction in such a manner or upon such a basis is authorized by the law of the state. These elements are hereinafter referred to as the jurisdictional facts, the jurisdictional basis, the jurisdictional conclusion, and the jurisdictional authorization. It may well be that the jurisdiction necessary to satisfy due process need not include the fourth element as will appear from the subsequent discussion. But these fundamentals underlie any solution to the question as to when an adjudication or recital of jurisdiction may be controverted.

Certain situations may be eliminated as not coming within the scope of the present discussion. The record of a judgment may or may not reflect the facts upon which the foreign court assumed jurisdiction to render the judgment. When there are facts recited in the record, and these facts alone are relied upon to support jurisdiction, and where it is apparent that they are not sufficient to support such jurisdiction, there is no particular problem involved since it is apparent from the record that the judgment is void and not entitled to full faith and credit.9 Thus in the case of Old

Scott, Jurisdiction over Non-Residents, 32 Harv. L. Rev. 87I (I9I9); Fead, Jurisdiction over Foreign Corporations, 24 Mich. L. Rev. 633 (I926); Farrier, Jurisdiction over Foreign Corporations, I7 Minn. L. Rev. 270 (1933).

19 Settlemier v. Sullivan, 97 U.S. 444 (1878); Pembleton v. Ill. Commercial Men's Assn., 289 Ill. 99, I24 N.E. 355 (I9rg), noted in 29 Yale L. J. 567 (I920).

The specific problem of contradiction of a finding of jurisdictional facts does not arise even where there is an attempt to show that jurisdictional facts other than those recited in the record existed. But the problem might seem to arise upon an attempt to show that a jurisdictional fact existed which is contrary to one recited. Thus the record may disclose that the defendant was not domiciled within the state and that the defendant was served with substituted service. If the record alone were relied upon it is apparent that the court did not have jurisdiction to render a personal judgment (see: Settlemier v. Sullivan, supra) and as a consequence the domestic forum should not recognize the judgment. However, suppose the plaintiff wishes to 
Wayne Mutual Life Assn. v. Flynn ${ }^{20}$ the plaintiff declared on a judgment reciting service upon a certain person not designated by statute nor connected with the defendant. It thus appearing that the attempt to secure jurisdiction was ineffective, a demurrer to the declaration was sustained. Similarly, in the case in which the record is silent as to the jurisdictional facts upon which the judgment is based, the problem under consideration does not arise. There being no jurisdictional facts appearing from the record there can be no contradiction of those facts and whether or not the court had jurisdiction to render the judgment can only be determined upon inquiry. ${ }^{2 \mathrm{~T}}$

Where the record recites facts sufficient to give the court jurisdiction, however, or there has been a prior adjudication of those facts and the defendant seeks to contradict them in the domestic forum in a suit on the judgment the problem is squarely raised.

\section{THE EFFECT OF A RECITAL OR UNCONTESTED ADJUDICATION}

It is generally stated as in the case of Smithman v. Gray, that when a suit upon a foreign judgment is brought, that judgment may be impeached for lack of jurisdiction in the foreign court irrespective of the recitals of jurisdiction contained in the record of judgment. ${ }^{23}$ The reasons assigned to this rule were stated in Thompson v. Whitman: $:^{24}$

show that while the record disclosed that the defendant was a non-resident, the latter was in fact domiciled within the state so that the foreign court was justified in assuming jurisdiction based upon substituted service. It is apparent that the admission of such evidence, while it may represent a contradiction of an adjudication or recital of jurisdictional facts, has no place in the present discussion since if it is so admitted the jurisdiction of the court rendering the judgment is upheld and there is no denial of full faith and credit. On the other hand if such evidence is not admitted there is no contradiction of the recital of jurisdictional fact.

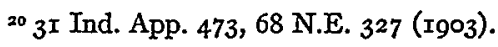

${ }^{21}$ It might be said that in every judgment there is an implied recital of jurisdiction since the court would not have rendered the judgment if it had not found that jurisdiction existed. See Chicago Life Insurance Company v. Cherry, 244 U.S. 25, 29 ( $\mathrm{IgI}_{7}$ ), "A court that renders judgment against a defendant thereby tacitly asserts, if it does not do so expressly, that it has jurisdiction over that defendant."

${ }_{22}^{203}$ Mich. 3x7, I68 N.W. 998 (IgI8).

${ }_{23}$ Similar statements are found in Banco De Sonora v. Morales, 23 Ariz. 248, 203 Pac. 328 (I922); O'Rourke v. C. M. \& St.P. R. R. Co., 55 Ia. 332, 7 N.W. $5^{82}$ (I880); Sullivan v. Kenny, I48 Ia. 36I, I 26 N.W. 349 (I9IO); Old Wayne Life Assn. v. Flynn, 3 I Ind. App. 473, 68 N.E. 327; Marshall v. R. M. Owen and Co., x7I Mich. 232, 137 N.W. 204 (1912); Moore v. Williams, IIx Neb. 342, rg6 N.W. 695 (r923); Hanna v. Stedman, 230 N.Y. 326, I30 N.E. 566 (Ig2r); Rice v. Bennett, 29 S.D. $34 \mathrm{I}$, i 37 N.W. 359 (I9I2); Wood v. Augustins, 70 Vt. 637 , 4 x Atl. 583 (I898); Carpenter v. Ritchie, 2 Wash. St. 5I2, 28 Pac. 380 (I89r).

24 I8 Wall. (U.S.) 457 ( 1873$)$. 
"But if it is once conceded that the validity of a judgment may be attacked collaterally by evidence showing that the court had not jurisdiction, it is not perceived how any allegation contained in the record itself, however strongly made, can affect the right so to question it. The very object of the evidence is to invalidate the paper as a record. If that can be successfully done no statements contained therein have any force. If any such statements could be used to prevent inquiry, a slight form of words might always be adopted so as effectually to nullify the right of such inquiry."25

However, prior to this decision the rule in some jurisdictions was to the contrary. ${ }^{26}$

Most of these cases have been overruled by decisions in accord with Thompson v. Whitman.

The record may recite that the defendant was personally served within the state, was domciled within the state, appeared without being served, consented to the judgment or that the defendant foreign corporation was doing business in the state, etc. For example, in the case of National Exchange Bank v. Wiley ${ }^{27}$ the plaintiff recovered a judgment in Ohio upon a note containing an authorization for any attorney to confess judgment in favor of the holder of the note. The judgment recited that an attorney acting by virtue of the warrant entered an appearance for the defendant and waived process. In a suit on this judgment in a Nebraska court the defendant contended that since the plaintiff bank had sold the note before the Ohio judgment was obtained, it was not the holder of the note and as a consequence the appearance recited was not in accordance with the defendant's authorization and that therefore the Ohio judgment was void. Such was the finding by the Nebraska court. Upon the question as to

${ }_{25}$ I8 Wall. (U.S.) 457,468 ( 1873 ).

${ }_{26}$ For example the Tllinois Court in the case of Zepp v. Hager, $70 \mathrm{Oll} .223$ (1873), was of the opinion that:

"The general doctrine no doubt is where it appears from the record, the court which pronounced the judgment had jurisdiction by service of process or personal appearance of the defendant it will under the Constitution and the Act of Congress be deemed conclusive of the rights of the parties and no evidence can be heard to impeach it."

Similarly in the case of Hall v. Williams, 6 Pick. (Mass.) 232 (1828), the court said:

"The full faith and credit required to be given in each state to the judicial proceedings of other States, will prevent any evidence to contradict the facts which show jurisdiction if such appear on the record."

See also Semple v. Glenn, gr Ala. 245 (I8gr); Bimeler v. Dawson, 4 Scam. (IIl) 536 (r843); Citizens' National Bank v. Consolidated Glass Co., 83 W.Va. I, 97 S.E. 689 (rgrg); $c f$. Welch v. Sykes, 3 Gilm. (Ill.) $x 97$ ( 1846 ), holding demurrer to plea that defendant was not a resident and made no personal appearance nor authorized any appearance should be overruled but that a demurrer to plea that defendant was not served with process and had no notice of the suit should be sustained.

${ }^{27}$ I95 U.S. 257 (I904). See also: Grover and Baker Sewing Machine Co. v. Radcliffe, I37 U.S. 287 (1890) and Forsyth v. Barnes, 228 Ill. 326, 8 I N.E. ro28 (1907). 
whether such a showing was proper the United States Supreme Court was of the opinion that:

"Proof that the payee bank was not the owner of the note when it brought suit in Ohio tended to show that it was not in law the 'holder' of the instrument within what must be regarded as the true meaning of the warrant of attorney, and therefore, that court was without authority to enter judgment by confession in its favor against the obligor. In other words, the defendant could show collaterally that he was not legally before the court, if his appearance was entered and judgment confessed by one who had in fact, at the time, no authority to do either." ${ }^{28}$

The court cites Thompson $v$. Whitman ${ }^{29}$ in support of its holding.

It will be noted in this case that it was admitted or assumed by both parties that the Ohio court was authorized to render a judgment based upon the jurisdictional facts recited in the record; that consent does furnish a valid basis for jurisdiction and that an appearance based upon a warrant of attorney does constitute consent to jurisdiction. The only question involved was whether or not the attorney was authorized to enter the appearance. Thus the attack is directed at the jurisdictional facts rather than the basis, conclusion or authorization.

The case of Pembleton v. Illinois Commercial Men's Assn. ${ }^{30}$ illustrates an attack upon the jurisdictional basis. In this case the acts of the defendant foreign corporation were admitted and it was further admitted that doing business is a valid jurisdictional basis, but the point contradicted was whether or not these acts of the defendant amounted to the doing of business within the state, i.e. the basis upon which jurisdiction was assumed.

Contrasting these cases with Pennoyer $v . N^{3} f^{3 x}$ it will be seen that in the latter case the attack is upon the jurisdictional conclusion rather than upon the jurisdictional facts or basis.

The jurisdiction sought in each of these cases is not jurisdiction as determined by the law of any particular jurisdiction. It is not a question of the law of the foreign or the domestic forum, but jurisdiction as determined by those principles fundamental in our system of law. That is, jurisdiction in the constitutional law sense of due process, since a judgment rendered without such jurisdiction is a violation of due process. ${ }^{32}$

${ }^{28} 195$ U.S. 257,268 (r904).

${ }^{29} \mathrm{I} 8$ Wall. (U.S.) 457 (1873). A rather unusual case illustrating the principle is that of Rice v. Bennett, 29 S.D. 34 r, I37 N.W. 359 (IgI 2), where the defendant in an action on a foreign judgment was allowed to show that though an attorney employed by the defendant to look after his interests appeared and waived process such attorney was not specifically authorized by the defendant to waive process and consequently the foreign court was lacking in jurisdiction.

${ }^{30} 289$ Ill. 99 , x 24 N.E. 355 (I9r9).

${ }^{31} 95$ U.S. 714 (I877).

32 See cases cited in supra note 9. 
The Supreme Court of the United States is consequently the final authority on such questions of jurisdiction.

It would seem then that a court not only may inquire into a foreign judgment to see whether or not it is a valid judgment, i.e. rendered without jurisdiction, but that the court must do so. The inquiry is whether such jurisdiction as stated above exists. This would seem to be so despite any adjudication or recital with reference to the jurisdictional basis or the jurisdictional conclusion upon which that judgment is based. Even though it is apparent that the foreign court determined its own jurisdiction upon what it conceived to be those general principles of our law relating to jurisdiction, the domestic court should not be bound thereby since the determination of jurisdiction must be in accord with such principles as have been promulgated by the Supreme Court of the United States. If the domestic forum decides that it must give full faith and credit to the foreign court's judgment based upon the latter's determination of these jurisdictional questions, when, as a matter of fact, according to the principles as laid down by the Supreme Court of the United States that jurisdiction does not exist, then could not its decision recognizing the foreigh judgment be attacked on the grounds of denial of due process?

If it is assumed that the domestic court cannot determine for itself the jurisdictional questions, the domestic court would seem to be caught in a dilemma. If it accepts the foreign court's determination it may be reversed on the grounds of denial of due process. If it refuses to accept that determination it may be reversed on the grounds of denial of full faith and credit. It would seem that upon such a theory no matter what the domestic court did it would be wrong. But if the domestic forum is always required to determine these jurisdictional questions by its own concept of the application of those principles, and its application of those principles is wrong, then if the domestic forum determines erroneously that the foreign court did not have jurisdiction as a matter of law, it is not the lack of the power of the court to inquire into the facts which is the error but the incorrect interpretation of those facts. This results in a denial of full faith and credit. The question in the last analysis depends upon the interpretation of those facts by the Supreme Court of the United States. Thus if the domestic court erroneously decides that jurisdiction did not exist there is a denial of full faith and credit. If the court erroneously decides that jurisdiction did exist then there is a denial of due process. In any event the court must inquire into the jurisdiction. The mere fact that the foreign judgment recites the jurisdictional facts, basis or conclusion, or contains an adjudication with respect thereto can have no bearing upon the 
right, power or duty of the domestic court to determine for itself those same questions. In such cases the denial of full faith and credit is not in the refusal of the domestic court to accept the foreign judgment without questioning its jurisdiction but in the erroneous decision that the foreign court did not have jurisdiction.

From this discussion it is apparent that the theory of Thompson $v$. Whitman ${ }^{33}$ encounters no difficulty so far as the jurisdictional facts, the jurisdictional basis and the jurisdictional conclusion are concerned.

The remaining question is the effect of the jurisdictional authorization. It naturally happens that different jurisdictions make different provisions relative to the rendition of judgments by their courts. These provisions are, of course, subject to certain minimum requirements necessary to due process but many impose additional requirements. For example some states require actual personal service regardless of domicil, while others consider merely prima facie evidence of personal service plus domicil as a sufficient basis for a personal judgment. In other words some states authorize a personal judgment based upon a sheriff's false return by reason of the rule that the sheriff's return cannot be impeached..$^{34}$ In the case of Miedrich v. Lauenstein ${ }^{35}$ it was held that such a rule was not a violation of the Due Process Clause of the Fourteenth Amendment. It would naturally seem to follow from this that a judgment based upon a sheriff's false return was a judgment founded upon good jurisdiction and consequently must be given faith and credit. Such, however, is contrary to unequivocal holdings in numerous cases. ${ }^{36}$

The consideration under the due process clause is directed specifically at those underlying principles of jurisdiction contained in what is here referred to as the jurisdictional basis and the jurisdictional conclusion. Thus assuming facts $A, B$, and $C$ to be true, are they sufficient to constitute the

33 I8 Wall. (U.S.) 457 ( 1873 ).

${ }^{34} \mathrm{No}$ attempt is made here to determine which jurisdictions retain this rule, because of the great confusion existing among the cases and the irrelevancy of the problem to the present discussion. It is sufficient for this criticism that such a rule still exists. See: McKnight v. Wilson, r58 Ga. I53, I22 S.E. 702 (x924); Smolinsky v. Federal Reserve Life Ins. Co., r 26 Kan. 506, 268 Pac. 830 (r928); United Drug Co. v. Cordley \& Hayes, 239 Mass. 334, I32 N.E. 56 (r92I); Clabaugh v. Wayne Circuit Judge, 228 Mich. 207, I99 N.W. 710 (I924); Jongewaard v. Gesquire, 5 I N.D. I73, I99 N.W. 585 (I924); McIntosh v. Holtgrave, 79 Okla. 53, I9I Pac. 739 (I920); F. P. Miller Paper Co. v. Keystone Coal and Coke Co., 267 Pa. I80, IIo Atl. 79 (I920); Turks Head Tailoring Co. v. Anthony, 38 R.I. 7, 94 Atl. 857 (Igr5).

35232 U.S. 236 (I9I4).

${ }^{36}$ See: Continental Supply Co. v. Whan, rrr Kan. 687, 208 Pac. $5^{6} 3$ (1922); Smolinsky v. Federal Reserve Life Ins. Co., I 26 Kan. 506, 268 Pac. 830 (I928); Price v. Schaeffer, I6r Pa. St. 530, 29 Attl. 279 (I894); Sutherland v. Peoples Bank, III Va. 5I5, 69 S.E. 34I (rgro). 
basis upon which the court assumed jurisdiction and further, does that basis justify the assumption of jurisdiction? The other element of due process is the sufficiency of the notice. ${ }^{37}$ In the Mildrich case it should be noted that the parties were both residents of Indiana. The court says:

"Without the necessity of deciding more in the present case, it is enough to say that the decision of the Supreme Court of Indiana, made under the circumstances detailed did not in our opinion deprive the plaintiff in error of due process of law within the meaning of the I4th Amendment." ${ }_{38}$ (italics supplied.)

This fact is of particular significance for it furnished a jurisdictional basis necessary to due process. It is not apparent in the Miedrich case whether the opinion was directed at the jurisdictional or the notice element of due process but it is not difficult to agree with the court that "under the circumstances," including the residence of both parties in Indiana, the due process clause was not violated. Domicil is one of the recognized grounds for jurisdiction. ${ }^{39}$

Since jurisdiction in the sense of due process exists, that is, since the facts of jurisdiction, the jurisdictional basis and conclusion are correct, the only remaining question is that of the jurisdictional authorization. In the Miedrich case there can be no doubt as to the authorization since it was approved by the Supreme Court of Indiana.

It has previously been contended that when such a judgment rendered upon a false return, is sued upon in another state the inquiry is shifted to "under what circumstances, if any do the laws in force in the various states make possible the rendering of a valid personal judgment without personal service." ${ }^{\circ 0}$ It was suggested that if the state where the judgment was rendered allows impeachment of the return, then the court where the judgment is presented may allow impeachment, but if the former does not then the latter must do the same.

It is suggested that the first inquiry is whether or not a valid basis for jurisdiction exists. If the defendants were not domiciled within the state and no other jurisdictional basis existed it would make no difference whether the laws of the state rendering the judgment allowed an impeachment of the return or not for in such case the jurisdictional conclusion or the jurisdictional basis would be in error and the judgment lacking in those

37 McDonald v. Mabee, 243 U.S. $9 \circ$ (Igr7); Skala v. Brockman, rog Neb. 259, Igo N.W. 860 (I922); Burdick, Service as a Requirement of Due Process in Actions in Personam, 20 Mich. L. Rev. 422 (x922).

${ }^{38} 232$ U.S. 236,247 (I9r4).

${ }^{39}$ See cases cited in supra note I5.

${ }^{40}$ See, The Conclusiveness of State Judgments under the Full Faith and Credit Clause, 28 Yale L. J. 579 (IgIg). 
essentials inherent in due process. Therefore the first question is as to the jurisdictional facts, the jurisdictional conclusion and the validity of the jurisdictional basis. Then, if it is determined that these are present and correct the inquiry is whether or not the laws of the state recognize such a basis. If impeachment of the return is allowed then such a basis for jurisdiction is not recognized under such circumstances, even though it might have been. If impeachment is not allowed according to the law of the state, then the assumption of jurisdiction under such circumstances is authorized. ${ }^{\mathrm{I}}$

Assuming that a jurisdictional basis exists other than actual personal service, such as domicil of the parties, the only question is what effect does the state where the judgment was rendered give to the judgment even assuming the return to be false. If that state refuses to recognize such a judgment, i.e. considers the judgment as void if based on a false return, then the domestic forum need not take cognizance of the judgment, still assuming that the return is false. But if that state recognizes such a judgment as valid, i.e. refuses to allow impeachment of the return, then the domestic forum must under the Full Faith and Credit Clause do the same. Such records are not void and so must "have such faith and credit given to them in every court within the United States as they have by law or usage in the courts of the state from which they are taken." ${ }^{2}$

On the other hand, if the only jurisdictional basis present is the personal service recited in the record, that is, if the judgment would be void as wanting in due process if the recited personal service were false, then the law of the state rendering the judgment with respect to impeachment of the return is immaterial. As was stated in the case of Cooper v. Nevell: $0^{43}$

"As any provisions by statute for the rendition of judgment against a person not a citizen or resident of a state, and not served with process or voluntarily appearing to an action against him therein, would not be according to the course of the common law, it must follow that he would befentitled to show that he was not such citizen or resident, and had not been served or appeared by himself or attorney." 44

43 As previously pointed out no attempt is made here to determine the law of the various states on this point, but the only indication which has come to the author's attention which indicates that perhaps the sheriff's return is not conclusive on collateral attack is the case of Unangst v. Southwick, 80 Neb. II2, Ir3 N.W. 989 (I907), 80 Neb. IIg, II6 N.W. 864 (Ig08). See also: McIntosh v. Holtgrave, 79 Okla. 63, I9I Pac. 739 (I920). As to whether in a suit on a foreign judgment the attack is direct or collateral see Kingsborough v. Tousley, 56 Ohio St. $45 \circ, 47$ N.E. 54I ( 1897 ).

42 I Stat. $x 22$ (I790), 28 U.S.C.A. $\$ 687$ (I928).

43 I73 U.S. 555 (I899).

44 I 73 U.S. 555,569 ( 1899$)$. 
Thus, the criticism previously referred to $0^{45}$ is in a large measure justified. Particularly the following statement and holding in the case of Chicago Title and Trust Company v. Smith ${ }^{4}$ is subject to criticism:

"When a judgment sued on here is not a domestic judgment and is one rendered in another state or jurisdiction the defendant may plead and prove that he was not duly served with process and did not authorize an appearance in the action in which judgment was entered." 47

The objection is not especially along the lines suggested in the note referred to $^{48}$ but because the statement does not consider that there might be, and in this case appeared to be, since both parties were residents of Illinois, any valid grounds for assuming jurisdiction other than personal service or appearance. Thus the statement would be correct if there were no other grounds for assuming jurisdiction present in the case. In the case of Wood v. Augustins ${ }^{49}$ the court more nearly covered the subject when it stated:

"We think the judgment in question could be collaterally attacked by evidence showing the court had no jurisdiction and the court should have received the evidence offered by the defendant for the purpose of showing that process was not served on him, that he was not an inhabitant of the state of Maine, that the person upon whom the officer certified he served the process was another person; that he made no appearance, etc. etc." ${ }^{50}$

Here was evidently an attempt to include every possible basis of jurisdiction and if it were shown that none existed the judgment would be void, but in the Smith case, even though it were conceded that the defendant "was not duly served with process and did not authorize an appearance" jurisdiction might still exist since both parties were residents of Illinois.

45 In the note previously cited, 28 Yale L. J. 579 (I9Ig), it is said by way of reasons why a court may lack power to render a judgment

". . . . because although these facts do exist (jurisdiction over this class of defendants) there has been no compliance with the rules of law in force in the particular State in question, which govern the acquisition by the Court of 'jurisdiction' to alter the defendant's legal relations." It is here contended that if jurisdiction is assumed upon such a basis as will keep the judgment from being void as wanting in due process, this question becomes merely one of the "effect of the judgment according to the law or usage of the state where rendered."

It is perhaps significant that the author of the note referred to adds in a footnote that there may be some distinction between a resident and a non-resident temporarily within the state who was not a citizen of the state.

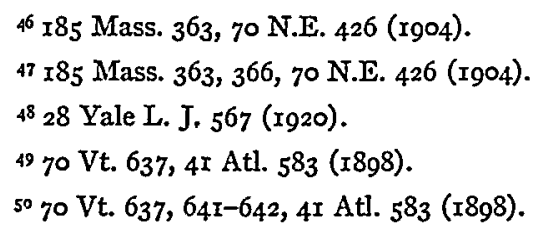


In other words if there are enough elements in a given situation to give the court jurisdiction without personal service there is a good due process jurisdiction and the only question remaining is the effect of the judgment in the state where rendered. If the judgment is not recognized there, because of the falsity of the return or for any other reason, the forum need not recognize the judgment under the Full Faith and Credit Clause even though the enforcement of that judgment would not be a denial of due process. But, if the service is, from the point of view of due process, necessary because of the absence of other sufficient jurisdictional elements then irrespective of the jurisdictional authorization, or what the state law may be, the falsity of the return may be shown.

\section{THE EFFECT OF A CONTESTED ADJUDICATION-PRTOR TO THE JUDGMENT}

The concept of the jurisdictional authorization here suggested is more fully illustrated in the case where the record discloses not merely a recital of jurisdiction but indicates that there has been an adjudication of that jurisdiction after a contested hearing at which both parties appeared and were heard upon the jurisdictional question. The case of Chicago Life Insurance Co. v. Cherry ${ }^{5 x}$ is particularly in point and has been subject to a great deal of misinterpretation.

In this case the plaintiff sued the defendant in Tennessee. In the Tennessee court the defendant raised the question of jurisdiction over the person and the matter was there litigated and found in favor of that jurisdiction and judgment was rendered against the defendant who made no further plea to the merits of the case. Thereupon the defendant carried the case to the Supreme Court of Tennessee and the ruling in favor of jurisdiction was affirmed by that court..$^{2}$ The plaintiff then brought suit upon the judgment in the Illinois court and the defendant again raised the question of the jurisdiction of the Tennessee court, contending the judg-

${ }^{5 x} 244$ U.S. 25 (19I7). Most of the material subsequently presented herein has been admirably considered from a realistic point of view by Medina, Conclusiveness of Rulings on Jurisdiction, 3 I Col. L. Rev. 238 (I93 $)$. In this article the author reached the conclusion, based upon the reasonableness, convenience and justice of the holdings, that "a defendant who appears specially to contest jurisdiction in personam under circumstances which constitute due process has so participated in the adjudication thus made as to give it the character and substance of a judgment entitled to full faith and credit." The present discussion is not to be considered antithetical to this conclusion but is merely an attempt to apply the existing legal theories of jurisdiction and to point out that no extension of our present jurisdictional concepts is necessary to the solution of the problems involved.

52 The Tennessee decision does not seem to have been reported. The statement of facts is taken from the United States Supreme Court decision cited supra, note 44. 
ment was void because of the lack of such jurisdiction. The Mllinois court refused to go into the matter and held that the Tennessee judgment was entitled to full faith and credit under the Constitution. The case was appealed to the Illinois Appellate Court and was affrmed on the grounds that the matter of jurisdiction, having been decided by the Tennessee court, was res adjudicata ${ }^{53}$ and that the Tennessee court's determination of jurisdiction must be given full faith and credit. The defendant then brought the case to the United States Supreme Court on the grounds that since the judgment was void, the action of the Illinois court amounted to a denial of due process under the Fourteenth Amendment.

The United States Supreme Court affirmed the decision of the Illinois court, not on the grounds of res adjudicata but on the grounds that:

"If a statute should provide that filing a plea in abatement, or taking the question to a higher court should have that effect, it could not be said to deny due process of law. The defendant would be free to rely upon his defense by letting judgment go by default. .... Whenever a wrong judgment is entered against a defendant his property is taken when it should not have been, but whatever the ground may be, if the mistake is not so gross as to be impossible in a rational administration of justice, it is no more than the imperfection of man, not a denial of constitutional rights." ${ }_{54}$

And after stating that the same could be true without a statute by such a construction by the courts of the state, the court is of the opinion that:

"It can be no otherwise when a court so decides as to proceedings in another State. It may be mistaken upon what to it is matter of fact, the law of the other State. But a mere mistake of that kind is not a denial of due process of law."ss

It will be noted that the court found jurisdiction existed, not because the Tennessee court had so adjudicated but because the defendant had appeared and defended even though that defense went only to the question of jurisdiction. This is in accord with the previous holdings of the court, particularly in connection with the cases of York v. Texas ${ }^{56}$ and Western Life Indemnity Co. v. Rupp. ${ }^{57}$

53 I90 Ill. App. 70 (1914).

55244 U.S. 25,30 (1917).

54244 U.S. 25,30 (1917).

${ }^{56}$ I37 U.S. I5 (I890).

57235 U.S. 26I (I9I4). In this case the court states:

"The Fourteenth Amendment declares that no State shall 'deprive any person of life, liberty, or property, without due process of law.' This prohibition has regard not to matters of form, but to substance of right. Since its adoption, whatever was the rule before, a non-resident party against whom a personal action is instituted in a state court without service of process upon him may, if he please, ignore the proceeding as wholly ineffective, and set up its invalidity if and when an attempt is made to take his property thereunder, or when he is sued upon it in the same or another jurisdiction. .... But if he desires to raise the question of the validity of the proceeding in the court in which it is instituted, so as to avoid even the semblance of a judgment against him, it is within the power of the State to declare that he shall do this subject to the risk of being obliged to submit to the jurisdiction of the court to hear and determine the merits, if the objection raised to its jurisdiction over his person shall be overruled." 
In such a situation the fact of appearing and contesting the jurisdiction is the jurisdictional fact; that such acts amount to a consent to jurisdiction is the conclusion and, of course, consent is a proper legal theory upon which jurisdiction may be based.

Consequently a state may prescribe that a voluntary special appearance in one of its courts, even for the bare purpose of litigating the jurisdictional question, shall be deemed a general appearance, without violating the Due Process Clause of the Fourteenth Amendment. As pointed out by the Supreme Court, this may be done by a statute ${ }^{5}$ or merely by such a construction by the courts of the state.

This constitutes the jurisdictional authorization.

Thus assuming 59 that such was the law of Tennessee, jurisdiction was properly assumed. Therefore the judgment could not be void and consequently not subject to the defense of lack of due process but must be given such faith and credit as it has by law or usage in Tennessee. But what if the law of Tennessee was not that a special appearance subjected the defendant to the jurisdiction of the court? Would this have made any difference? The Cherry case answers this question by holding in effect that such a basis for jurisdiction exists in Tennessee as well as in every other state.

If a judgment is rendered after a contested adjudication of jurisdiction, which, according to the law of the state where rendered, constitutes a valid judgment even though predicated, perhaps erroneously, upon another basis of jurisdiction, the enforcement of that judgment by another state is not a denial of due process. Thus suppose the case had not been passed upon by the Tennessee Supreme Court and the lower court had not been specifically authorized by the law of Tehnessee to assume jurisdiction in such a case. Under such circumstances could it be said that the action of the Illinois court amounted to a denial of due process in enforcing the Tennessee judgment? Obviously the answer is in the negative.

Due process jurisdiction and the authority to exercise that jurisdiction are entirely different matters. If the former existed, the action of the

${ }^{8} 8$ In addition to the Texas statute upheld in the case of York v. Texas, ${ }_{37}$ U.S. I5 (x89o), a Kentucky statute provides that s special appearance by a corporation for the purpose of quashing the service of summons operates as a general appearance and if the objection is sustained the appearance may stand for trial at the succeeding term of court. See Texas Laws (1889I890) I35, and Maysville etc. R. Co. v. Ball, I08 Ky. 24I, 56 S.W. I88 (I900). See also: Towa Code (I897), § 354r; Blondel v. Ohlman, I32 Iowa 257, rog N.W. 806 (rgo6); Miss. Code (rgo6), § 3946; ㄲll. Cent. R. Co. v. Swanson, 92 Miss. 485 , 46 So. 83 (rgo8).

59 This assumption is contrary to fact since Tennessee has not specifically authorized the assumption of jurisdiction based upon the defendant's special appearance. See: Sherry v. Divine, rr Heiske. (Tenn.) 722 (I872); Boon v. Rahl, I Heiske. (Tenn.) I2 (I870); Mark Twain Lumber Co. v. Lieberman, ro6 Tenn. I53, 6r S.W. 70 (r900). 
Tennessee court in assuming jurisdiction could not be void even though it might be in error as to its theory of jurisdiction or as to the authority to exercise that jurisdiction. Similarly the action of the Illinois court in enforcing the judgment would not be a denial of due process even though the Illinois court might be in error as to the authorizations made by the law of Tennessee.

Here is a judgment which is valid according to the law of the state where rendered. If the allegations of the defendant are to be taken as true, as they might well be since it is held that those allegations are immaterial, no basis for jurisdiction exists except the fact that the defendant appeared and contested the jurisdictional question. This jurisdictional basis is not specifically authorized by the state rendering the judgment. Yet the enforcement of that judgment is not a denial of due process. Does it not follow then that such a basis for jurisdiction exists in the state even though a court is not specifically authorized by the law of that state to assume jurisdiction upon such a basis in the first instance?

As pointed out by the United States Supreme Court ${ }^{60}$ the question of full faith and credit is another question and if the Illinois court had decided that the law of Tennessee did not authorize the judgment and had refused to recognize it, then the Supreme Court would have been called upon to decide whether or not the Illinois court had violated that section of the Constitution. In such a case it could not be contended that the judgment was void and so not entitled to full faith and credit since an underlying basis of jurisdiction exists. Consequently the only question would be the effect of such a judgment according to the law or usage of Tennessee.

There can be no question but that a judgment rendered after the defendant has appeared and contested the jurisdiction is valid. Under the facts of the Cherry case it would appear that since the judgment is considered a valid and existing obligation according to Tennessee law ${ }^{6 \mathrm{x}}$ it must under the full faith and credit clause be given the same effect in Illinois. This it is submitted, is the significance of the question of jurisdictional authorization. Thus there are two questions. First, is the judgment valid as judged by the standard of due process of law? And second, if so what is its effect in the state where rendered? Not the effect of a

${ }^{60}$ Chicago Life Ins. Co. v. Cherry, 244 U.S. 25 (I9I7). At page 30 the court observes, "If the Tennessee judgment had been declared void in Illinois this court might have been called upon to decide whether it had been given due faith and credit."

6r It rould seem that this would follow from the fact that the judgment was upheld by the highest court of the State. Note here that the theory of the jurisdiction used by the Tennessee court is immaterial. 
judgment based upon such a theory of jurisdiction but the actual effect of this particular judgment in the state where rendered. It might well be that if the law of Tennessee did not authorize such a judgment it would not enforce it. On the other hand it might consider, perhaps erroneously, this judgment valid on some other grounds, as was no doubt the case here since the judgment was upheld by the highest court of that state. Or the law of Tennessee might specifically authorize the judgment upon such a jurisdictional basis. Whatever the status of the particular judgment according to the law of the state where rendered, the courts of Mllinois and every other state are bound by the Constitution and the act of Congress to give "said records and judicial proceedings, so authenticated .... such faith and credit .... as they have by law or usage in the courts of the state from which they are taken." ${ }^{62}$ If the Illinois court decides incorrectly on this point and enforces the judgment no problem is raised since there is no denial of the judgment ${ }^{63}$ and there is no lack of due process since the fundamental basis for jurisdiction is there. On the other hand if the court decides incorrectly as to the law of Tennessee with respect to this judgment and refuses to enforce it, then that court is not conforming to that section of the Constitution and the act of Congress previously quoted. ${ }^{64}$

The case of Hall v. Wilder Manufacturing Company ${ }^{65}$ presents practically the same problem as the case of Chicago Life Insurance Co. v. Cherry ${ }^{66}$ The language of the court, while seemingly quite rational might be quoted either in support of or antithetical to the concepts herein suggested. In this case Bogert and Hopper, Incorporated, sued the Wilder Manufactur-

${ }_{62}$ I Stat. I22 (I 790), 28 U.S.C.A. $\$ 687$ (I928).

${ }^{6}$ In all of the cases which have come to the attention of the author the question of full faith and credit has been raised by the party relying upon the judgment. The usual case follows somewhat the following sequence: The plaintiff secures a judgment against the defendant in state $A$ and sues the defendant in state $B$ on that judgment. The court of state $B$ refuses to recognize the judgment and the plaintiff attacks the decision on the ground that the court violated Article 4 Section I of the Constitution. But suppose the court in state B recognized the judgment as valid. Could the defendant then urge that the Full Faith and Credit Clause was violated on the ground that according to the "law and usage" of state A the judgment, not being authorized, would not be enforceable in state $A$ even though state $A$ could so enforce the judgment without a violation of due process?

${ }^{64}$ See supra notes I and 2.

${ }^{65} 3$ I6 Mo. 812, 293 S.W. 760 ( 1927$)$. See also the case of Semple v. Glenn, 9x Ala. 245, 9 So. 265 (r8gr) where in a suit to recover an assessment ordered by the Virginia court in which court jurisdiction had been attacked and sustained, the court holds that full faith and credit must be given the Virginia decision. No reason is given, the court merely stating, "but the decrees are not void and we are bound to accord to them the same faith and credit they have by law and usage in the courts of Virginia."

${ }^{66} 244$ U.S. 25 (I9I7). 
ing Company in a New York court. The defendant appeared to raise the question of jurisdiction of the court over its person and upon evidence submitted by the parties upon that question, the court found in favor of jurisdiction. As a result judgment was rendered in favor of the plaintiff and the defendant did not appeal from this adverse ruling. The present plaintiff, Hall, being the assignee of the judgment, brought suit on the judgment in the Missouri court and the defendant sought to avoid the judgment on the grounds that it was void since the New York court erroneously held it to be doing business within the state of New York. It was admitted by the defendant that the doing of business within a state was a valid ground for the court to assume jurisdiction. Thus there was no objection to the jurisdictional conclusion of the court. Further, certain facts as found by the court to exist were admitted. These were the jurisdictional facts. In this case the attack was upon the New York court's determination of what it conceived to be the jurisdictional basis.

The court, however, seems to overlook another jurisdictional fact, basis and conclusion which was admitted by the parties:

"It is conceded that a special appearance of the defendant did not constitute a general appearance to the action, nor confer jurisdiction over the person of the defendant." 67

It may be true that a judgment predicated upon such a basis was not authorized by the law of New York but it nevertheless does prevent the judgment from being void from the due process point of view.

Later, however, the court argues:

"Having procured the New York court to exercise its power upon the question of jurisdiction over the person of the defendant and to enter into an authorized inquiry as to such jurisdiction and directly determine that question before proceeding to judgment upon the merits, the defendant submitted itself to that court for the determination of that question, taking the chance that an adverse ruling, unreversed and not appealed from, would preclude inquiry into the same question when sued upon the judgment in the court of another State. Upon that question and by that court the defendant was given the benefit of 'due process' by the submission of the question upon the evidence offered and a hearing thereon in due and orderly manner." 68

This would seem to indicate that the Missouri court was not concerned with the actions and adjudications of the New York court, but rather was determining jurisdiction for itself from the actions of the defendant and consequently deciding, not that the New York court's jurisdiction was based upon the doing business by the defendant as determined by that

${ }^{67} 3 \mathrm{r} 6 \mathrm{Mo}$. 812, 820, 293 S.W. 379 (I927).

${ }^{68} 3$ I6 Mo. 8I2, 827, 293 S.W. 379 (I927). 
court but rather upon the fact that the defendant appeared and contested the jurisdictional question.

Later in the opinion the court seems to go back to the concept that the New York court determined jurisdiction and so the Missouri court is bound thereby. The court specifically remarks that it believes the principal of res adjudicata to be applicable. It is submitted that such a principle of res adjudicata has no place in the consideration of whether or not full faith and credit should be given to a judgment of a sister state. A foreign court's determination of a jurisdictional question can no more make jurisdictional facts true when the determination is contested than when that determination is a mere recital. However, there is this distinction between the two types of determination of jurisdictional facts: In the latter case, i.e. recital, jurisdiction is based upon certain recited facts as found by the foreign court while in the former case the jurisdiction is not dependent upon the facts as found by the foreign court, but rather it is apparent from the acts of the defendant in appearing and contesting the issue.

The res adjudicata theory might be said to have been properly used in the case of Baldwin v. Traveling Men's Assn.69 In this case a judgment was secured in the United States District Court of Missouri. The jurisdiction was attacked, but the issue was determined in favor of that jurisdiction. No further plea was made. Subsequently an action was brought upon this judgment in the United States District Court of Iowa. The Iowa District Court held that the matter of the jurisdiction of the District Court in Missouri was conclusive. Here the Supreme Court of the United States pointed out that the full faith and credit clause of the Constitution was not involved, since neither of the courts concerned was a state court..$^{70}$ In answer to the question of a violation of due process the court stated:

${ }^{6} 283$ U.S. 522 (I93I).

${ }^{70}$ Baldwin v. Traveling Men's Assn. supra note 69, 524. On the relation between the Federal Courts and the Full Faith and Credit Clause of the Constitution see: Embry v. Palmer, IO7 U.S. 3, 9 (1882) (judgment rendered in U.S. Dist. Ct. brought to a State Court in Conn.; held Full Faith and Credit Clause applied); Hancock National Bank v. Farnum, r76 U.S. 640 (Ig00), (U.S. District Court of Kansas judgment in a State Court of R.I.); Pennoyer v. Neff 95 U.S. 714, 732 (1877) (State Court judgment in a Federal Court); Cooper v. Newell, I73 U.S. 555 (1899) (State Court judgment in a Federal Court). In Knights of Pythias v. Meyer, 265 U.S. 30 (1924), it was said, "While the judicial proceedings of the Federal Courts are not within the terms of the Constitutional provision (Art IV. § r), such proceedings, nevertheless, must be accorded the same full faith and credit by state courts as would be required in respect of the judicial proceedings of another State." In Cooper v. Newell, x73 U.S. 555 (1899), the court is of the opinion:

"The courts of the United States are bound to give to the judgment of the State Courts the same faith and credit that the courts of one State are bound to give to the judgments of the courts of her sister States." 
"But there is involved in that doctrine no right to litigate the same question twice. ... . Public policy dictates that there be an end of litigation; that those who have contested an issue shall be bound by the result of the contest, and that matters once tried shall be considered forever settled as between the parties. We see no reason why this doctrine should not apply in every case where one voluntarily appears, presents his case and is fully heard, and why he should not, in the absence of fraud, be thereafter concluded by the judgment of the tribunal to which he submitted his cause."'7x

The holding in this case is not inconsistent with the language previously quoted in the case of Chicago Life Insurance Co. v. Cherry $y^{72}$ nor is it in conflict with the present criticism of the use of the res adjudicata theory in the Wilder Manufacturing Company case. In the Baldwin case the judgment could not have been enforced if jurisdiction had not existed because of due process, but if jurisdiction did exist, whether or not the judgment should be recognized is merely a question of the law of the Federal Courts, since the full faith and credit clause of the Constitution has no application. Consequently, this case merely approves a rule of procedure similar to that which, as has been pointed out, obtains in other situations, namely that when one appears and contests the jurisdiction of the court before judgment on the merits there can be no objection on the grounds of lack of due process when an attempt is made to enforce that judgment if the court decided in favor of jurisdiction. Therefore, since jurisdiction did exist the question is merely one of Federal law as to whether or not the judgment should be recognized. In this case the Supreme Court decided that under the res adjudicata doctrine the Federal law should be that the defendant should not be allowed to re-litigate the same questions. It is apparent that this reasoning is different from the res adjudicata theory used in Hall v. Wilder Manufacturing Company. ${ }^{73}$ There the court seems to consider that the question of jurisdiction was res adjudicata since the Full Faith and Credit Clause required the domestic forum to accept the previous determination of jurisdiction and therefore the court was bound under the Full Faith and Credit Clause to enforce the judgment.

Such arguments as res adjudicata and attempts to determine the correctness of the foreign court's determination of the contested issue of jurisdiction merely confuse the issue. Appearing and contesting the jurisdiction involves fundamentally a submission to jurisdiction and has a jurisdictional value as such. If this fact exists it is not of prime importance whether the foreign court rests its conclusion of jurisdiction upon that ground or upon some other. The jurisdiction is in fact there. The validity

$$
\begin{aligned}
& \pi_{28} \text { U.S. } 522,524,525-526 \text { (I93I). } \\
& 7_{244} \text { U.S. } 25 \text { (r9r 7). }
\end{aligned}
$$$$
{ }^{73} 3 \text { r6 Mo. 812, } 293 \text { S.W. } 760 \text { (r927). }
$$ 
of the judgment does not depend upon the jurisdictional authorization. The fact that the law of the foreign state does not authorize a judgment based solely upon an appearance to contest the jurisdiction is immaterial to the validity of a judgment when such a basis does in fact exist.

THE EFFECT OF A CONTESTED ADJUDICATION SUBSEQUENT TO THE JUDGMENT

The case of Simmons Co. v. Sloan ${ }^{74}$ presents a different aspect of the effect of an adjudication with respect to jurisdiction. In this case Simmons Co. sued Grange and Sloan as partners in a New York court. Grange only was served and judgment was rendered against him. Subsequently upon application of a firm of lawyers the judgment was opened and an answer filed for both Grange and Sloan and judgment was rendered against both. Later Sloan by special appearance sought to have the judgment set aside on grounds that at the commencement of the suit he was not a resident, had not been served, was not a partner and had not authorized any attorney to represent him. The court refused to set aside the judgment and upon appeal to the Appellate Division the judgment was affirmed. The action now is in a New Jersey court upon the judgment. The New Jersey Court rendered a verdict against Sloan and an appeal was taken upon the grounds that the New York judgment, being rendered without jurisdiction was a nullity. This argument the appellate court rejected and affirmed the judgment of the lower court, saying:

"He had, therefore, litigated unsuccessfully these very questions in a court of competent jurisdiction, and we think the judgment of such court is conclusive and res adjudicata of such question in the courts of this state. Such is the holding in the United States Supreme Court in Chicago Life Insurance Co. v. Cherry, by which, in matters of this character, dealing with judicial transactions between states resting upon mandates of the federal constitution, we are bound, and accordingly accept as the law of the land."75

It is submitted that the reasoning of the court in the Cherry case does not carry the implication given to it by the New Jersey court in the above case. Specifically the court in the Cherry case rather negatives the conclusion reached by the New Jersey court in the Sloan case. In the former the court states with reference to the holding of the Mlinois Court that the matter was res adjudicata:

"The ground upon which the present judgment was sustained by the Appellate Court was that as the issue of jurisdiction over the parties was raised and adjudicated after full hearing in the former case it could not be reopened in this suit. The matter

$$
\begin{aligned}
& { }^{74} \text { ro4 N.J.L. 6r2, I42 Atl. I5 (I928). } \\
& { }^{75} \text { IO4 N.J.L. 6r2, 6r4-6r5 (r928). }
\end{aligned}
$$


was thought to stand differently from a tacit assumption or mere declaration in the record that the court had jurisdiction. A court that renders judgment against a defendant thereby tacitly asserts, if it does not do so expressly, that it had jurisdiction over that defendant. But it must be taken as established that a court cannot conclude all persons interested by its mere assertion of its own power, even where its power depends upon a fact and it finds the fact." 76

This language of the Supreme Court certainly cannot be used to sustain any holding that once a court decides upon a contested hearing that certain jurisdictional facts exist, the decision is res adjudicata upon the existence of those jurisdictional facts when that question is raised in the courts of another state. In fact it would seem to indicate the exact opposite. That is, a court cannot conclude jurisdictional facts so as to be binding upon all other courts by merely making an adjudication with reference to those particular jurisdictional facts, even if that adjudication is contested.

The facts of the Cherry case also are entirely distinct from trying the case on the merits first and then later upholding the jurisdiction upon a contested hearing as was apparently done in the Sloan case. In the former case there exists a fundamental basis of jurisdiction. The court may certainly say that if you come into our courts for the purpose of determining a jurisdictional question we shall consider that you have consented to our determination of the merits if it should so happen that we decide in favor of that jurisdiction. But it might be a different thing for a state to say to a defendant that if you subsequently attack the jurisdiction of our courts over your person we shall take it that you previously consented to our determination of the merits of the case if it should happen that we decide that you were previously subject to the jurisdiction of the court. It might seem that either the court had jurisdiction over the defendant to decide upon the merits of the case at the time the decision was made or it did not. It is perhaps difficult to see how a subsequent determination of that jurisdiction can affect its actual existence. Can a court render a valid judgment without jurisdiction and subsequently have that jurisdiction supplied by some act of the defendant? If so, then it is possible that the defendant's subsequent special appearance but not the court's determination of jurisdiction might supply that jurisdiction necessary to keep the judgment from being void. It is not necessary at this point to decide this question.

In the case of Howard v. Smith ${ }^{77}$ the New York court upon practically identical facts as in the Sloan case reached a contrary decision. This ac-

${ }^{6} 244$ U.S. 25,29 (I9I7).

${ }_{77} 3$ Jones \& S. (N.Y.) r3I (I872). 
tion was a suit in the New York court upon a California judgment. There had been no special appearance in the California court before the judgment was rendered but after the judgment had been entered the defendant appeared specially and sought to be relieved of the judgment upon the grounds that the court had no jurisdiction over him and that the person who previously had appeared for him was unauthorized. This application was denied. In the suit upon the California judgment the New York court held that the defendant should be allowed to show that the California court did not have jurisdiction in spite of its adjudication. The grounds for this holding was that it would be oppressive and unjust to hold that, although the appearance was unauthorized the defendant was bound by the judgment until he could get it opened in the court where it was rendered and that if it were a nullity it was sufficient for him to show it to be so when it was attempted to be enforced. The court was of the opinion that the denial of the motion to set aside the judgment did not make the question res adjudicata.

As previously pointed out, when it is admitted that the defendant appeared and contested the point of jurisdiction before the judgment was rendered this question of res adjudicata is entirely irrelevant since certain primary jurisdictional facts are admitted to exist, which, as decided by the United States Supreme Court, do as a matter of law constitute a valid jurisdictional basis. ${ }^{78}$ That is, even a special appearance may as a matter of law act as a consent to the jurisdiction of the court's subsequent determination of the case upon its merits. Consent may form a perfectly valid ground for so assuming jurisdiction. When that appearance comes subsequent to the rendition of the judgment, however, the same jurisdictional facts do not exist, though it may be that the jurisdictional basis and jurisdictional conclusions are the same. Nevertheless unless this theory of res adjudicata can furnish other jurisdictional facts and conclusions it can: not be said that jurisdiction exists because of the adjudications of the foreign court.

It is at once apparent that the mere deciding of these questions by the foreign court can have no bearing upon its previous power to render a judgment on the merits any more than the deciding of these questions before judgment can give the court jurisdiction. Jurisdiction exists in both cases, if at all, because of the action of the defendant in appearing and contesting the jurisdiction and not because the foreign court determined that jurisdiction did exist.

${ }^{8}$ York v. Texas, $x_{37}$ U.S. I5 (I89o); Kaufman v. Wooters, $x_{3} 8$ U.S. 285 (I89r); Western Life Indemnity Co. v. Rupp, 235 U.S. 26I (I9I4). 
It must be remembered that certain facts are admitted to be true and these facts are not only those considered by the foreign court but any others that may appear from the record or be shown to exist. The only question is whether any or all of these facts do as a matter of law constitute a basis upon which as a matter of law the court might have assumed jurisdiction. If the foreign court erroneously determines those matters of law in favor of jurisdiction is there any principle of public policy involved which prevents another court from refusing to recognize or requires the recognition of the resulting judgment? The jurisdiction of the court cannot be based upon the principles applied by that court since they are erroneous. Since jurisdiction is not to be determined by the law of the foreign court but rather by the law of due process, the judgment cannot be sustained upon the ground that the foreign court determined jurisdiction. Therefore, if the mere raising of the jurisdictional point after the judgment does not amount to such consent as to render the court's prior acts valid, the conclusion must be that the judgment is void and there is nothing in the principles of res adjudicata which favors the recognition of a void judgment.

The present criticism is not directed at the decision in either the case of Simmons v. Sloan ${ }^{79}$ or that of Howard v. Smith, ${ }^{80}$ but rather at the erroneous reasoning upon which both decisions are based. However, it may be noted that a general appearance after judgment, just as before judgment, corrects all defects in the court's jurisdiction over the person. ${ }^{8 \mathrm{r}}$ And while it is generally held that a special appearance after judgment, just as before judgment, does not validate a judgment void for want of jurisdiction, ${ }^{82}$ the contrary has been held. ${ }^{83}$ From this it would seem that according to the theory of Chicago Life Insurance Co. v. Cherry, ${ }^{84}$ the decision in the case of Simmons $v$. Sloan, ${ }^{85}$ is correct since the principles involved appear to be the same whether the jurisdictional question is litigated before or after judgment.

$$
79 \text { I04 N.J.L. 6r2, I42 Atl. I5 (I928). } \quad{ }^{80} 3 \text { Jones \& S. (N.Y.) I3I (1872). }
$$

8x See: Thompson v. Alford, I35 Cal. 52, 66 Pac. 983 (rgor); Aherne v. WaKeeney Land etc. Co., 82 Kan. 435, xo8 Pac. 842 (rgro); Tootle-Weakley Millinery Co. v. Billingsley, 74 Neb. 53r, 105 N.W. 85 (r905); Tisdale v. Rider, rI9 App. Div. 594, I04 N.Y.S. 77 (1907); Wickham v. South Shore Lumber Co., 89 Wis. 23, 6I N.W. 287 (I894).

${ }^{82}$ See: Gray v. Hawes, 8 Cal. 562 (1857); Abrams v. Fine, 28 Misc. 533,59 N.Y.S. 550 (I899); Jacobs v. Atlas Constr. Co., IIg N.Y.S. 168 (Ig09).

${ }_{83}^{8}$ See: H. L. Griffin Co. v. Howell, $3_{8} \mathrm{Utah} 357$, Ir3 Pac. $3^{26}$ (IgIr), indicating that such an appearance makes the judgment binding unless appealed from after a decision refusing to vacate the judgment.

84244 U.S. 25 (I9I7).

${ }^{85}$ IO4 $_{4}$ N.J.L. 6r2, I42 Atl. I5 (r928). 
The whole question can be determined by a demurrer to the allegation that the foreign court's determination of jurisdiction was in error. Admitting that the determination was erroneous and jurisdiction could not be based upon the theory used by the foreign court the question still remains whether or not jurisdiction did exist, not because of, but in spite of that determination. If the defendant appeared and contested the jurisdiction then the resulting judgment is not void and the defendant's contention that the foreign court erroneously determined jurisdiction is immaterial.

Most of the cases seem to consider that there can be only one basis for jurisdiction and that the recital of that basis is the finding sought to be contradicted. Thus in the case of contradiction of the sheriff's return the cases seem to go on the assumption that if the return is false there was no personal service and the judgment void. So also in the case of a foreign corporation. If the corporation were not doing business in the state, it is thought that the judgment is void regardless of other considerations. It is suggested that this reasoning is fallacious since there may be, and in most of the cases here considered there are, other grounds upon which jurisdiction might rest. Any allegation that there was no personal service or that the defendant foreign corporation was not doing business in the state where the judgment was rendered would be irrelevant when it is apparent from the record that jurisdiction might properly rest on other grounds even though the foreign court erroneously thought it could assume jurisdiction upon the basis of the type of service or the extent of doing business or some other jurisdictional basis and apparently acted upon that basis rather than upon any other grounds which might also exist. But when the judgment is presented in another state the inquiry is not necessarily whether or not the foreign court was correct in its theory of jurisdiction but rather whether its assumption of jurisdiction can be sustained upon any grounds.

In the case of recital or adjudication concerning the jurisdictional facts, the burden is naturally upon the one denying those facts and here the question arises as to how far must he go in negativing jurisdiction. ${ }^{86}$ The answer is that the jurisdictional facts necessary to jurisdiction must be overcome. Further than that it would seem not necessary for him to go.

The important point here emphasized is that all facts contained in the record upon which jurisdiction could be based must be contradicted and

${ }^{86}$ On the general question of presumptions in this connection see: Galpin v. Page, I8 Wall. (U.S.) $35^{\circ}$ (I873). Settlemier v. Sullivan, 97 U.S. 444 ( 1878 ); Green v. Equitable Mut. Life and Endowment Assn., I05 Ia. 628, 75 N.W. 635 (r898); Marshall v. R. M. Owen \& Co., I7I Mich. 232, r37 N.W. 204 (rgr2). 
not merely those which the foreign court considered to be pertinent to the theory of jurisdiction considered by that court. Thus if it appears from the record that the defendant by any act or circumstance was subject to the exercise of jurisdiction by the foreign court and that jurisdiction was exercised, the judgment is not void regardless of what theory was used by the foreign court but is entitled to have "such faith and credit given to it in every court within the United States as it has by law or usage in the courts of the state from which it is taken," 87 unless every such recital of such acts or circumstances upon which jurisdiction might be based is refuted.

If in a given case there are enough elements to give the foreign court jurisdiction irrespective of the particular basis considered by that court and the authorization of the state law, there is good due process jurisdiction and the judgment is entitled to be given the same effect in the domestic forum as it has in the foreign state.

On the other hand if the only possible basis for jurisdiction is that considered or recited by the foreign court then the correctness of that decision or recital not only may but must be inquired into. Again the question of whether or not the foreign court was authorized by the state law to render such a judgment is immaterial except insofar as it relates to the effect of that judgment in the jurisdiction where rendered.

From this it will readily be seen that the solution of the problems presented involves the proper application of existing principles of jurisdiction rather than any extension of those principles or any addition thereto.

${ }^{87}$ I Stat. I22 (1790), 28 U.S.C.A. $\$ 687$ (1928). 